Winter 2008

\title{
the Hague Convention: The Problems with Accession and Implementation
}

Annette Schmit

Indiana University School of Law

Follow this and additional works at: https://www.repository.law.indiana.edu/ijgls

Part of the International Law Commons

\section{Recommended Citation}

Schmit, Annette (2008) "the Hague Convention: The Problems with Accession and Implementation," Indiana Journal of Global Legal Studies: Vol. 15 : Iss. 1 , Article 15.

Available at: https://www.repository.law.indiana.edu/ijgls/vol15/iss1/15

This Note is brought to you for free and open access by the Law School Journals at Digital Repository @ Maurer Law. It has been accepted for inclusion in Indiana Journal of Global Legal Studies by an authorized editor of Digital Repository @ Maurer Law. For more information, please contactrvaughan@indiana.edu.

\section{$\Psi$}

JEROME HALL LAW LIBRARY

INDIANA UNIVERSITY

Maurer School of Law
Bloomington 


\title{
The Hague Convention: The Problems with Accession And Implementation
}

\author{
Annette Schmit*
}

Abstract

The Hague Convention on Protection of Children and Co-operation in Respect of Intercountry Adoption ("the Hague Convention") was developed to enable adoptions to proceed according to the "the best interests of the child with respect for his or her fundamental rights." This Note discusses the dynamics of the Hague Convention with respect to the implementation process and the relationships between members of the Convention that are abiding by Hague Convention standards, members of the Convention that are not abiding by Hague Convention standards, and non-members of the Convention.

The United States' recent ratification of the Hague Convention exemplifies the difficulties of implementing Hague Convention standards and the changing relationships between itself and sending countries. Member countries of the Hague Convention are the sending countries most likely to realize positive changes in adoption relationships through the United States' ratification. But, problems with non-members and members not abiding by Convention standards, namely Guatemala, frustrate the goals of the Hague Convention. However, the United States plans to continue adoptive relationships with non-member sending countries and plans to refuse those relationships with member countries not abiding by Convention standards. This Note argues adoptive relationships between member countries should continue with those members not abiding by Convention standards if relations are continued with non-member countries. This reasoning is explored through the United States' relationship with Guatemala and the difficulties Guatemala faces implementing Convention standards.

* J.D., 2008, Indiana University School of Law-Bloomington; B.S., 2005, Butler University. I would like to thank my brothers and my parents who have always believed in me and who have loved and supported me. I would also like to thank Richard Lifshitz for reviewing my note and for his suggestions.

Indiana Journal of Global Legal Studies Vol. 15 \# (Winter 2008)

(OIndiana University School of Law 


\section{INTRODUCTION}

Madonna and Angelina Jolie are not merely known for their star status, but also for glamorizing foreign adoptions. The glamour quickly fades as the realities of intercountry adoption processes become known. Madonna's controversy regarding the adoption of a Malawian boy, David, has drawn media attention because David's father claimed he did not understand he was giving up custody of his son. ${ }^{1}$ Angelina Jolie was one of the first celebrities to popularize adopting from disease stricken countries with poor living conditions. Jolie has adopted three children: Maddox, Zahara, and Pax from Cambodia, ${ }^{2}$ Ethiopia, and Vietnam respectively. ${ }^{3}$ The validity of Jolie's adoption of son Maddox has been questioned because the woman who helped Jolie adopt later pled guilty to various charges related to other parents' intercountry adoptions. ${ }^{4}$ However, the controversies surrounding the adoptions of Madonna and Jolie are only a few of the problems facing those seeking intercountry adoptions.

Prospective parents are subject to the laws and restrictions of the country in which they seek to adopt a child without redress through laws of their own coun-

1. Daniela Deane, Madonna Speaks Out on Adoption, Washington Post Newsweek InterncTive, Oct. 25, 2006, http://www.washingtonpost.com/wp-dyn/content/article/2006/10/25/ AR2006102501243.html?nav=rss_world/africa. For the first interview with Madonna about her interim adoption, see also The Oprah Winfrey Show, Madonna: The Adoption Controversy, http://www2.oprah.com/tows/slide/200610/20061025/slide_20061025_350_102.jhtml (last visited May 12, 2008). The Malawian government granted Madonna an interim adoption. The interim adoption will last 18 months and a social worker will be required to visit Madonna's home during this time period before she can legally adopt David. The purpose of the interim adoption is to verify that the child is not neglected or mistreated.

2. On December 21, 2001, the United States suspended the adoption of children through the Cambodian government by United States citizens because of concerns about Cambodia's adoption processes, child trafficking, and widespread corruption. Important Update Regarding Cambodia Adoptions, Feb. 12, 2002, available at http://travel.state.gov/family/adoption/country/country_361.html.

3. Kay Johnson, Meet Angelina's Boy: Pax Thien Jolie, TIme, March 15, 2007, available at http:// www.time.com/time/arts/article/0,8599,1599341,00.html; Karen Thomas, Choosing a Child from Overseas, USA Today, Oct. 13,2006, at 2E, available at http://www.usatoday.com/life/people/200610-12-celeb-adoptions_x.htm.

4. Lauryn Galindo, Jolie's adoption agent, was part of a ring that paid foreign mothers for their babies. The lowest price given to a mother was $\$ 100$. ABC News ONLINE, Angelina Jolie's Adoption Agent Admits Fraud, June 25, 2004, http://www.abc.net.au/news/newsitems/200406/s1140807.htm. Galindo was convicted of conspiracy to commit visa fraud, conspiracy to commit money laundering, and structuring currency transactions. United States v. Galindo, 161 F. App'x 735, 736, 2006 WL 172061 (9th Cir. 2006). 
try. ${ }^{5}$ The differing legislation from country to country creates difficulty preventing problems such as "abducting children, exchanging a child for financial or material rewards to the birth family, child buying, deliberately providing misleading information to birth parents to obtain their consent, providing false information to prospective adopters, falsifying documents, and obtaining favorable adoption decisions from corrupt local or central government officials." The Hague Convention on Protection of Children and Co-operation in Respect of Intercountry Adoption was established to promote intercountry adoptions that are "in the best interests of the child with respect for his or her fundamental rights" and to prevent such child trafficking problems.

Increased globalization and interconnectedness of countries has created a need for general guidelines that can be implemented throughout the world and applicable to various forms of government. The development of the Hague Convention was an outgrowth of globalization and acceptance of the treaty is necessary to encourage global, societal interests in protecting children. The increased interdependency of countries with regards to adoption also creates a need for the Hague Convention. However, the United States' ratification of the Hague Convention leaves the future of intercountry adoptions from certain countries unclear. ${ }^{8}$ The United States still plans to allow adoptions from countries that are not members of the Hague Convention. ${ }^{9}$ However, adoptions with member countries of the Hague Convention that have not abided by Convention guidelines may halt. If adoptions are allowed from non-members, adoptions should also be allowed from member countries that have yet to fully implement Hague Convention guidelines.

Part I of this note explores the United States' implementation of the Hague Convention through intercountry adoption processes. Part II of this note discusses the United States' ratification of the Hague Convention and explores the effects

5. See U.S. Department of State, Intercountry Adoption, http://travel.state.gov/family/adoption/ adoption_485.html (last visited Feb. 27, 2008).

6. United States Government Accountability Office, Report to the Chairman, Committee on Foreign Relations, U.S. Senate, Foreign Affairs-Agencies have Improved the Intercountry Adoption Process, but Further Enhancements Are Needed 25 (Oct. 2005), hitp:// frwebgate.access.gpo.gov/cgi-bin/getdoc.cgi? dbname = gao\&docid =f:d06133.pdf [hereinafter GAO].

7. The Hague Conference on Private International Law, Final Act of the Seventeenth Session, Including the Convention on Protection of Children and Co-operation in Respect of Intercountry Adoption, Convention No. 33, May 29, 1993, 32 I.L.M. 1134, art. 1 [hereinafter Hague Convention].

8. The United States was permitted to object to member countries that acceded prior to the United States' ratification so that adoptions would not be conducted between the United States and those countries under the Convention. Id. at art. 44.

9. GAO, supra note 6 , at 32 . 
on sending countries ${ }^{10}$ that are members of the Convention, members of the Convention that are not abiding by Convention guidelines, and non-members. Part III of this note examines the need for the United States to allow adoptions from all member countries and to continue allowing adoptions from sending countries that are non-members of the Hague Convention.

\section{Hague Convention: Steps Toward Ratification}

Adoption laws around the world differ greatly with respect to children's rights and subsets of those rights regarding biological parents and prospective parents." The Hague Convention sceks to advance the protection of "the best interests of the child" by creating a more uniform system to accomplish this goal. ${ }^{12}$ The United States is used as an example of the implementation process to meet requirements of the Hague Convention, because it has recently executed the necessary steps of the process. ${ }^{13}$ An understanding of this process illuminates the complexities and the difficulties a country might encounter in attempting to meet the requirements of the Hague Convention.

\section{A. Reasons for Signing the Hague Convention}

The ever increasing number of foreign adoptions presents a need for a more unified system. In 2006, the United States issued approximately 20,000 visas to children adopted from foreign countries. ${ }^{14}$ The number of visas issued in 2006 for adopted children was more than double the number of visas issued in 1994, the year the United States signed to become a member of the Hague Convention. ${ }^{15}$ Over the last five years, parents have adopted over 100,000 children from many different

10. Sending countries are defined, for the purposes of this note, as those countries that allow adoption by United States citizens.

11. See Hague Convention, supra note 7, at arts. 4-5.

12. Maura Harty, Assistant Secretary for Consular Affairs, U.S. Department of State, Remarks at the Holt International Conference on "Looking Forward: A Global Response to Homeless Children" (Oct. 20, 2006), available at http://travel.state.gov/law/legal/testimony/testimony_3069.html.

13. Catherine M. Barry, Deputy Assistant Secretary for Overseas Citizens Services, U.S. Department of State, Status of the U.S. Implementation of Hague Convention on Intercountry Adoptions (Nov. 14, 2006), available at http://travel.state.gov/law/legal/testimony/testimony_3091.html.

14. U.S. Department of State, Immigrant Visas Issued to Orphans Coming to the U.S., http:// travel.state.gov/family/adoption/stats/stats_451.html [hereinafter Immigrant Visas] (last visited Feb. 27, 2008).

15. See id. 
countries with many different legal procedures. ${ }^{16}$ The United States became a member of the Hague Convention in order to protect parents and children involved in intercountry adoption processes and to support the growing number of children being adopted from foreign countries. Benefits of the Hague Convention include more uniform requirements for processes between member countries, safeguards for parents adopting from member countries, families for children that meet their best interests, and common recognition of adoptions among member countries. ${ }^{17}$

The Hague Convention serves to protect and promote intercountry adoption by preventing corruption, child trafficking, child sales, and abductions from birthparents. ${ }^{18}$ There are numerous examples of these injustices. For example, in Guatemala, females pose as mothers to give permission for the adoption of children when they have no legal rights to the children. ${ }^{19}$ Another problem in Guatemala pertains to child buying. Adoption attorneys give payments to birth mothers, and in return, the birth mothers surrender their rights so that other parents may adopt the children. ${ }^{20}$ Other problems include fraudulent documents. There have been problems with fraudulent documents in Nepal, Nigeria, and Sierra Leone. ${ }^{21}$ In addition, Cambodia is a prime example of abuses the Hague Convention is trying to inhibit, and as a result, the United States has suspended adoptions from Cambodia. Baby buying, alien smuggling, visa fraud, false passports, and money laundering were several of the offenses that led to the suspension on adoptions. ${ }^{22}$

While the Hague Convention is not perfect, it provides a solution to many of the problems associated with intercountry adoptions. The United States "support[s] the Convention because it is flexible, to account for different systems and models of child welfare systems throughout the world. ${ }^{23}$ Member countries of the Hague Convention have different types of government structures that can range from communism to democracy, but the Convention standards are applicable and flexible enough to fit different government systems. Members of the

16. Harty, supra note 12.

17. U.S. Department of State, Hague Convention: Advantages and Provisions (Apr. 2005), http:// travel.state.gov/family/adoption/convention/convention_2300.html.

18. See 42 U.S.C. $\$ 14901$ (b)(2) (2000).

19. GAO, supra note 6, at 26; U.S. Department of State, Intercountry Adoption: Guatemala (Sept. 2007), http://travel.state.gov/family/adoption/country/country_389.html [hereinafter Intercountry Adoption: Guatemala].

20. GAO, supra note 6 , at 26.

21. Id.

22. Id. at 25-26.

23. Harty, supra note 12. 
Hague Convention must conform to rules that guarantee certain procedures will be followed to protect the parties involved in the adoption.

The implementation of Hague Convention guidelines may take various forms depending on the country, but the benefits will be the same. The receiving country, the United States, obtains the benefits of the Hague Convention through the establishment of a Central Authority overseeing the obligations of the Convention including: approval of accredited agencies and compliance with reporting requirements, ${ }^{24}$ the determination by proper authorities that the prospective parents are eligible and suitable to adopt ${ }^{25}$ the assurance by proper authorities that the prospective parents have received proper counseling, ${ }^{26}$ the conclusion by proper authorities that the child may enter and permanently live in the State, ${ }^{27}$ the assurance that improper fees have not been acquired due to the adoption, ${ }^{28}$ and the guarantee by proper authorities that the adoption has taken place according to Hague Convention standards. ${ }^{29}$

\section{B. Past Steps Taken to Implement the Hague Convention}

On December 12, 2007, the United States ratified the Hague Convention, but it will take effect on April 1, 2008..$^{30}$ The United States chose to adhere to Hague Convention standards prior to ratification. ${ }^{31}$ Despite the United States signing to become a member of the Hague Convention in 1994, it did not implement any legislation to formally adhere to its standards until 2000, when the Intercountry Adoption Act was passed. ${ }^{32}$ Conformity with Hague Convention standards is currently a high priority for the United States. ${ }^{33}$

The Hague Convention requires a Central Authority to oversee its require-

24. See Hague Convention, supra note 7, arts. 6-13.

25. Id. at art. 5.

26. Id.

27. Id.

28. Id. at art. 32 .

29. Id. at art. 23.

30. U.S. Department of State, U.S. Hague Convention Ratification (Dec. 12, 2007), http://travel state.gov/family/adoption/convention/convention_3900.html.

31. United States Department of State Bureau of Consular Affairs, The Hague Convention on Intercountry Adoption: A Guide for Prospective Parents 5 (Oct. 2006), http:// travel.state.gov/pdf/Prospective_Adoptive_Parents_Guide.pdf [hereinafter Prospective Adoptive PARents]; GAO, supra note 6, at 30.

32. Intercountry Adoption Act of 2000, Pub. L. No. 106-279, 114 Stat. 825 (2000).

33. See U.S. Department of State, Implementation of the Hague Convention on Intercountry Adoption (Feb. 15, 2006), http://www.state.gov/r/pa/prs/ps/2006/61274.htm [hereinafter Implementation]. 
ments. ${ }^{34}$ The United States has designated the Department of State to manage the transition and to act as the Central Authority. ${ }^{35}$ The Secretary of State is the leader of the Central Authority and has control over various aspects of the Hague Convention's implementation and relations with member countries. ${ }^{36}$

Determinations about a prospective parent's suitability for adoption and a child's appropriate status as an orphan are important preliminary steps in the adoption process and help facilitate compliance with Hague Convention requirements. The first step in the formal adoption process is an evaluation of the prospective parent's suitability. ${ }^{37}$ Suitability ${ }^{38}$ is determined by the U.S. Citizenship and Immigration Services (USCIS), which carries out the requirements of the Immigration and Nationality Act (INA). ${ }^{39}$ The second step of the process involves a determination about the orphan status of a child to ensure that the child is not being fraudulently bought or sold..$^{40}$ The USCIS and the Department of State work together to determine whether "the child is an orphan as defined by U.S. immigration law."41 To ensure that a child is an orphan, the USCIS must sometimes visit the biological mother and orphanage. ${ }^{42}$ The third step in the process handles the child's admission into the United States and verifies documents involved in the adoption. ${ }^{43}$ This includes a medical exam of the child for communicable diseases and a showing of legal documents for the adoption. ${ }^{44}$ The medical tests are used to determine if the child has a disease not mentioned in the orphan petition. ${ }^{45}$ There are no mental ex-

34. Hague Convention, supra note 7 , at art. 6 .

35. 42 U.S.C. $\$ 14911$ (a)(1) (2000).

36. 42 U.S.C. $\$ 14911$ (a)(2) (2000); see also 42 U.S.C. $\$ 14912$ (2000) (explaining the Secretary's duties as liaison between Convention countries and responsibilities regarding reporting and accreditation).

37. GAO, supra note 6 , at 13.

38. Suitability is determined through home studies, compliance with state law adoption requirements, and other documents. Id. The home studies must be approved by an accredited adoption agency under Convention requirements. U.S. Department of State, IAA: Summary of Provisions (Apr. 2005), http://travel.state.gov/family/adoption/convention/convention_2308.html [hereinafter Summary of Provisions].

39. Immigration and Nationality Act of 1952, Pub. L. No. 82-414, 66 Stat. 163 (1952).

40. 8 U.S.C. $\$ 1101$ (b)(1)(F) (2000).

41. U.S. Citizenship and Immigration Services, Overseas Orphan Investigation, http://www .uscis.gov/portal/site/uscis/menuitem.5af9bb95919f35e66f614176543f6dla/?vgnextoid = af5796981 298d010VgnVCM10000048f3d6a 1 RCRD\&vgnextchannel = 063807b03d92b010VgnVCM10000045 f3d6a1RCRD [hereinafter USCIS] (last visited Feb. 27, 2008).

42. GAO, supra note 6 , at 14 .

43. Id. at 15 .

44. Id.

45. USCIS, supra note 41. 
aminations or complete exams for physical health of the child during this step. ${ }^{46} \mathrm{~A}$ child who cannot meet these standards may be inadmissible to the United States. If the requirements are met, a visa is issued for the child.

Another crucial step for implementing the Hague Convention is the accreditation process of adoption agencies. Under implementing legislation, adoption service providers that facilitate adoption must first be accredited or approved. ${ }^{47}$ The Secretary is charged with designating accrediting entities that will carry out the duty of approving other adoption service agencies. ${ }^{48}$ The Colorado Department of Human Services and the Council on Accreditation (COA) were designated as the accrediting entities assigned the duty of approving adoption service providers in the United States. ${ }^{49}$ The main accrediting agency is the COA. The COA is responsible for evaluating an agency's compliance with accreditation standards, and it has the power to nationally approve adoption agencies for accreditation. ${ }^{50}$ The COA is also responsible for monitoring and overseeing the accredited agencies. ${ }^{51}$

The guidelines used by the COA for evaluation of agencies seeking accreditation include: "licensing and corporate governance, financial and risk management, ethical practices and responsibilities, professional qualifications and training for employees, information disclosure, fee practices, quality control policies and practices, respon[se] to complaints, records and reports management, service planning and delivery, and standards for cases in which a child is immigrating to the United States in connection with an adoption." ${ }^{\text {2 }}$ The applicant for accredita-

46. GAO, supra note 6 , at 15.

47. 42 U.S.C. $\$ 14921(2000)$.

48. 42 U.S.C. $\S 14922(2000)$.

49. Barry, supra note 13.

50. See generally Hague Convention on Intercountry Adoption, 22 C.F.R. $\$ \S 96.29-96.55$ (2006) (explaining guidelines and requirements for agencies to become accredited).

51. Accrediting Entities' Duties Include: (1) determining whether agencies or persons are eligible for accreditation/temporary accreditation/approval; (2) monitoring the performance of accredited agencies, temporarily accredited agencies, and approved persons; (3) investigating and responding to complaints about accredited agencies, temporarily accredited agencies, and approved persons; (4) taking disciplinary action against accredited agencies, temporarily accredited agencies, and approved persons, when appropriate; (5) determining whether accredited agencies and approved persons are eligible for renewal of their accreditation/approval; (6) collecting data from accredited agencies, temporarily accredited agencies, and approved persons, maintaining records, and reporting information; and (7) assisting in the transfer of Convention adoption cases and adoption records if an agency or person loses its accreditation, temporary accreditation, or approval. U.S. Department of State, Hague Convention Accreditation and Approval: What Your Organization Needs to Know, http://travel.state .gov/family/adoption/implementation/implementation_2806.html\#partl_3 [hereinafter Convention Accreditation and Approval] (last visited Feb. 27, 2008).

52. Prospective Adoptive Parents, supra note 31 , at 7. 
tion need not meet the extensive list in full, but must be in "substantial compliance" with the requirements..$^{53}$ Accreditation ensures that particular services will be provided to the prospective parent and adopted child. ${ }^{54}$

\section{Future Requirements of the Convention}

The Secretary is required to set up a case registry system to track adoption cases. ${ }^{55}$ The database that will be used to carry out this requirement is the Adoptions Tracking Service (ATS). ${ }^{56}$ The purpose of the ATS is to "track all incoming and outgoing adoption cases involving the United States; manage and track the accreditation/approval status of adoption service providers; manage adoption service provider[s] and accrediting entity contact information; and produce Congressional and management reports and correspondence for the Department of State." 57 The case registry will include valuable information about the sending countries involved in each adoption for each agency, the number of children adopted, the date the children were placed for adoption, the state the adopted children live in after adoption, and the age of the children. ${ }^{58}$ The information provided in this database will be supplied by the accredited agencies.

Another system for reporting will be the Hague Complaint Registry (HCR) which will be used to track complaints with regards to adoptions that occur under

53. Id.

54. Adoption Services for which the organization needs to be accredited: (1) identifying a child for adoption and arranging an adoption; (2) securing consent to termination of parental rights and to adoption; (3) performing a home study and report on prospective adoptive parent(s) or a background study and report on a child; (4) making a non-judicial determination of a child's best interests and of the appropriateness of an adoptive placement; (5) monitoring a case after a child has been placed with prospective adoptive parent(s) until final adoption; and (6) assuming custody of a child and providing child care or any other social service, when necessary because of a disruption pending alternative placement. Convention Accreditation and Approval, supra note 51; see also Hague Convention, supra note 7, at arts. 9-11 (describing the duties of accredited agencies).

55. 42 U.S.C. $\$ 14912$ (e) (2000).

56. See U.S. Department of State, The Adoptions Tracking Service, http://travel.state.gov/family/ adoption/implementation/implementation_2816.html (last visited Feb. 27, 2008).

57. Id.

58. Hague Convention on Intercountry Adoption, 22 C.F.R. $\S 96.43$ (2006). The development "of those ATS components to be used by accrediting entities and adoption service providers" is complete. Barry, supra note 13. Information about particular cases can be entered into the ATS. Michael Bond, Deputy Assistant Secretary for Overseas Citizens Services, U.S. Department of State, Letter to Adoption Service Provider Applicants, http://www.travel.state.gov/family/adoption/intercountry/ intercountry_3826.html (last visited June 14, 2008). 
the Hague Convention. ${ }^{59}$ Information regarding complaints within the system could prove to be the most valuable part of the HCR because it would provide indications of problems, which, unchecked, could lead to criminals capitalizing on abuses to the detriment of the children and parents involved. The establishment of a formal system for documenting problems associated with intercountry adoption will allow the United States to analyze the extent of these problems within foreign countries and to gain access to information about organizations engaging in behavior harmful to intercountry adoption processes that would otherwise be difficult to obtain. ${ }^{60}$ The HCR database will hold information regarding the complaint, the solution, the actions taken to solve the complaint, and the deadlines for resolving the complaints. ${ }^{61}$ The HCR will also have the capacity to analyze information to recognize trends in the complaints. ${ }^{62}$ One caveat for the complaint system to be effective is that it relies on parties to the adoption, whether parents or third parties, to communicate complaints. If they do not, the value of the complaint system will be significantly diminished, and many problems will be left undiscovered and unresolved.

\section{Effects Of Ratification On Sending Countries}

The United States' ratification of the Hague Convention will have numerous effects on sending countries. ${ }^{63}$ It is no surprise that adoption relations between the United States and other countries are subject to change. For member countries, it is highly probable that adoptions will proceed according to the Convention standards. For non-member countries, adoptions are likely to proceed as normal. However, for member countries unable to abide by Hague Convention guidelines, adoptions may halt.

\section{A. Member Countries of the Convention}

Ratification of the Hague Convention will have the most positive effect on member countries of the Convention, because it will facilitate adoptions based upon a more standardized system and the best interest of the child. Sending countries must abide by Hague Convention guidelines through the establishment of a

59. Convention Accreditation and Approval, supra note 51.

60. GAO, supra note 6 , at 5 .

61. Hague Convention on Intercountry Adoption, 22 C.F.R. $\$ \S 96.70-96.72$ (2006).

62. Id. at $\S 96.70$.

63. Barry, supra note 13. 
Central Authority overseeing the obligations of the Convention including approval of accredited agencies and compliance with reporting requirements, ${ }^{64}$ the determination by proper authorities that the child is eligible for adoption, ${ }^{65}$ the conclusion by proper authorities that State placement in the sending country is not in the best interests of the child, ${ }^{66}$ the written consent of the proper party relinquishing the child after proper counseling, ${ }^{67}$ the assurance that improper fees have not been acquired due to the adoption, ${ }^{68}$ and the guarantee by proper authorities that the adoption has taken place according to Convention standards. ${ }^{69}$

The Hague Convention standards will apply between the United States and member countries. Under the Hague Convention, member countries are able to object to countries that are acceding to the Convention, or, if the country is ratifying the Convention, it can object to countries that acceded to the Convention prior to its own ratification. ${ }^{70}$ Objecting to a member country precludes the Hague Convention's applicability between the country that objected and the country that was objected to. ${ }^{71}$ For example, Guatemala's accession to the Hague Convention was objected to by Canada, Germany, Netherlands, Spain, and the United Kingdom because Guatemalan adoptions have yet to meet the requirements of the Convention. $^{72}$

Ratification of the Hague Convention will improve relationships between the United States and member countries, provided that the countries involved in the adoptions are following Convention standards. There are approximately 70 countries that are members of the Hague Convention. ${ }^{73}$ In 2005, 58.2 percent of intercountry adoptions in the United States were from member countries. ${ }^{74}$ One of the major players for adoption among member countries is China. ${ }^{75}$ In 2006, the

64. Hague Convention, supra note 7, arts. 6-13.

65. Id. at art. 4.

66. Id.

67. Id.

68. Id. at art. 32 .

69. Id. at art. 23.

70. Id. at art. 44.

71. See Hague Conference on Private International Law, Details, http://hcch.e-vision.nl/index _en.php?act =status.comment\&csid =767\&disp=type [hereinafter Hague Details] (last visited Feb. 27, 2008).

72. Id.

73. Prospective Adoptive Parents, supra note 31 , at 5.

74. Percentage includes the number of children adopted from Guatemala, which is considered a member of the Convention by the United States, even though it has not implemented the requirements but has agreed to abide by Convention standards. Implementation, supra note 33 .

75. The People's Republic of China. 
United States issued 6,493 visas for adoptions of Chinese children. ${ }^{76}$ China is the top sending country and has been the top sending country since $2000,{ }^{77}$ despite only acceding to the Hague Convention in 2005..$^{8}$

The United States' ratification also means that more member countries will be able to open their doors to the United States. Specifically, some member countries only allow adoptions from other member countries that have fully implemented the Hague Convention's requirements. ${ }^{79}$ Thus, United States citizens will be able to adopt from these more demanding member countries, thereby increasing the number of children available for adoption.

\section{B. Member Countries Not Abiding by the Convention}

The relationship between the United States and member countries not abiding by Hague Convention guidelines will likely cause the United States to discontinue adoptions between those countries. One way to explore the ramifications of a member country unable to implement the Hague Convention is to examine the relationship between Guatemala and the United States. Guatemala is in a unique position with regards to the applicability of the Hague Convention between it and member countries. It acceded to the Hague Convention in 2003, but has not taken significant steps to abide by Convention standards. ${ }^{80}$ On August 13, 2003, the Guatemalan Constitutional Court determined that Guatemala's accession to the Hague Convention was unconstitutional..$^{81}$ Because of the problems with constitutionality, Guatemala viewed itself as a non-member of the Hague Convention until May 22, 2007, when the Congress of Guatemala finally passed legislation approving the Hague Convention. ${ }^{82}$ The prior situation was further complicated by the Vienna Convention, which explains that "a State may not invoke the fact that its consent to be bound by a treaty has been expressed in violation of a provi-

76. Immigrant Visas, supra note 14.

77. Id.

78. Hague Conference on Private International Law, Status Table, http://hcch.e-vision.nl/ index_en.php? act $=$ conventions.status \& $\&$ cid $=69$ (last visited Feb. 27, 2008).

79. Examples include: Bolivia, Paraguay, and the Slovak Republic. Joint Council on International Children's Services, Bolivia, http://www.jcics.org/Bolivia.htm; Joint Council on International Children's Services, Paraguay, http://www.jcics.org/Paraguay.htm; Joint Council on International Children's Services, Slovak Republic, http://www.jcics.org/Slovak\%20Republic.htm.

80. Hague Details, supra note 71; Harty, supra note 12.

81. Hague Details, supra note 71.

82. Congressional Coalition on Adoption Institute, http://www.ccainstitute.org/detail.php? id $=150$ (last visited March 27, 2008). 
sion of its internal law regarding competence to conclude treaties as invalidating its consent unless that violation was manifest and concerned a rule of its internal law of fundamental importance. ${ }^{" 83}$ Guatemala had acceded to prior treaties and considered itself a member of those treaties. ${ }^{84}$ The Court did not consider those accessions unconstitutional..$^{85}$ Therefore, the United States has always viewed Guatemala as a member country because it acceded to the Hague Convention and is bound by international law. ${ }^{86}$

The United States is prepared to stop adoptions from Guatemala if the latter does not make headway to meet requirements before the Hague Convention takes effect in the United States. ${ }^{87}$ "Pursuant to our commitment to the Hague Convention, the Department has made clear to all appropriate Guatemalan government agencies that we will not continue adoptions from that country unless they comply with the Hague Convention standards." ${ }^{88}$ One prior option for the United States if it had wanted to halt adoptions between the two countries was to object to Guatemala's accession when the United States ratified the Hague Convention. ${ }^{89}$ Because of the United States' devotion to the Hague Convention and its view that Guatemala is bound by international law, it is encouraging compliance. The United States is working with Guatemala to encourage conformity with the Hague Convention, and Guatemala has vowed that adoption reform is a priority. ${ }^{90}$ However, considering the length of time the United States has taken to implement the Hague Convention, the prospect of Guatemalan conformity before enforcement by the United States seems bleak. ${ }^{11}$

83. Vienna Convention on the Law of Treaties, art. 46, May 23, 1969, 1155 U.N.T.S. 331. See U.S. Department of State, Frequently Asked Questions: Intercountry Adoptions and the Hague Convention: Guatemala, http://travel.state.gov/family/adoption/notices/notices_2859.html [hereinafter Frequently Asked Questions] (last visited Feb. 27, 2008).

84. Frequently Asked Questions, supra note 83.

85. See id.

86. See id.

87. U.S. Department of State, Warning: Adoptions Initiated on or after December 31, 2007 in Guatemala (Jan. 9, 2008), http://travel.state.gov/family/adoption/intercountry/intercountry_3927.html.

88. Barry, supra note 13.

89. Hague Convention, supra note 7, at art. 44; Frequently Asked Questions, supra note 83.

90. Harty, supra note 12.

91. Id. 


\section{Non-Member Countries to the Convention}

Adoptions between non-member countries and the United States will not change after the Hague Convention takes effect in the United States and adoptions will continue according to non-member countries' laws. ${ }^{92}$ The number of countries that fall within this category are too numerous to name. The United States has shown concern with many non-member countries' adoption procedures and has attempted to work with several, including Vietnam, ${ }^{93}$ Cambodia, ${ }^{94}$ and Ukraine, ${ }^{95}$ to name a few, "to encourage transparency in laws, policies and procedures, to promote reforms consistent with Hague Convention goals; and to do what is in the best interest of the child concerned. ${ }^{.96}$ However, the United States' ratification of the Hague Convention has no effect on non-member countries and adoptions will proceed as normal.

\section{Dealing With The Discrepancies Between Member Countries Not Abiding By The Convention And Non-Member Countries}

There is a troubling problem in allowing non-member countries to continue adoptions with prospective parents from the United States while there is a possibility of discontinuing adoptions with member countries that have yet to implement Hague Convention requirements. It punishes countries that have agreed to Convention requirements but have yet to implement them, while rewarding non-member countries by allowing those countries to ignore Convention requirements. Nonmember countries are still able to have adoptive relations with the United States and other member countries. As a result, a non-member country has no incentive to formally agree to the Hague Convention, especially considering the risk of a member country prohibiting adoptions if that country cannot adequately take steps to implement the Convention, like Guatemala. Banning adoptions from Guatemala

92. See Prospective Adoptive Parents, supra note 31 , at 5.

93. A bilateral agreement was reached in 2005 so that adoptions could resume. Harty, supra note 12. See also Agreement Between the United States of America and the Socialist Republic of Vietnam Regarding Cooperation on the Adoption of Children (2005), available at http://travel.state.gov/pdf/ vn_final_agreement.pdf (documenting the agreement between the United States and Vietnam).

94. The United States has worked with Cambodia in an attempt to lift the suspension and to provide the country with information about a study that found 8,000 children in institutions. However, the United States has refused to lift the suspension until more laws in Convention-like form are imposed. Harty, supra note 12.

95. The United States' work with Ukraine has consisted of urging U.S. parents to abide by postadoption reporting. Id.

96. Id. 
because it is not in compliance with the Hague Convention, even though it has taken more steps toward adoption improvement than non-member countries, is not advancing Convention compliance and is harming adoptable children.

\section{A. Disincentives for Becoming a Member Country of the Convention}

Non-member countries have no legal incentive to accede to the Hague Convention and to be formally bound by the Hague Convention because adoptions will not be discontinued between member and non-member countries so long as blatant violations are not found. ${ }^{97}$ This also encourages dishonesty by non-member countries in any reporting requirements member countries impose to keep adoption relations open. ${ }^{98}$ It gives non-member countries an incentive to hide corruption for fear that suspension could be placed on adoptions. Joining the Hague Convention would be a disincentive for non-member countries because if they were to formally agree to Convention standards and were later not able to implement the Convention, they could be forced into the same situation as Guatemala ${ }^{99}$ and face having adoptions discontinued or restricted. ${ }^{100}$

Member countries are encouraging non-member countries to adopt Hague Convention-like guidelines. ${ }^{101}$ Non-member countries are not obligated to abide by Convention guidelines in adoption processes because they are not bound by international law and the Hague Convention. Non-members must only abide by adoption standards that receiving countries might place on the non-member

97. For an example of violations causing the United States to suspend adoptions with another country, see U.S. Department of State, Intercountry Adoption: Cambodia, http://travel.state.gov/ family/adoption/country/country_361.html [hereinafter Cambodia].

98. The new ATS system also tracks adoption cases from non-member countries. Hague Convention on Intercountry Adoption, 22 C.F.R. $\$ 96.43$ (2006).

99. "Guatemala is recognized as a party to the Hague Adoption Convention under international law. But Guatemala has not implemented the Convention, and its current adoption process is not consistent with Hague principles for the protection of children and families." Hague Convention on International Adoptions: Status and the Framework for Implementation: Before the Subcomm. on Africa, Global Human Rights and International Operations, 109th Cong. 10 (2006) (statement of Lori Scialabba, Associate Director, Refugee, Asylum and International Operations Directorate, U.S. Citizenship and Immigration Services), available at http://www.foreignaffairs.house.gov/ archives/109/30901.pdf.

100. "Canada, Germany, and Britain already restrict Guatemalan adoptions because of apparent breaches." Marc Lacey, Guatemala System is Scrutinized as Americans Rush in to Adopt, N.Y. Times, Nov. 5, 2006, available at http://www.nytimes.com/2006/11/05/world/americas/05guatemala.html ? pagewanted $=2 \& \mathrm{ei}=5088 \& \mathrm{en}=4888 \mathrm{bb} 2 \mathrm{c} 86 \mathrm{el} \mathrm{fl} 185 \& \mathrm{ex}=1320382800 \&$ partner $=$ rssnyt $\&$ emc $=$ rss .

101. See Harty, supra note 12. 
countries. In addition, non-member countries "face greater potential costs of joining a treaty to the extent that they expect it to be monitored and enforced." 102 With the Hague Convention enforcement that Guatemala has encountered, non-member countries are not likely to be encouraged to accede to the Convention. If member countries will continue to adopt from non-member countries without any changes, there is no incentive for non-member countries to deplete resources or begin the time-consuming process to implement the Hague Convention.

Even if non-member countries want to implement the Hague Convention, many of the countries do not have a structured legal system to do so. The Hague Convention is designed to work with many different governmental and legal structures, ${ }^{103}$ but it is difficult to implement adequately when a country is dealing with other problems such as political transformation, widespread poverty, violent crimes, inadequate police enforcement, or an insufficient judicial system. ${ }^{104}$ The problems with implementation overlap with current domestic problems and the above mentioned reasons are sometimes the underlying reasons for inability to implement the Hague Convention. ${ }^{105}$ Due to these concerns, it would be next to impossible for non-member countries to implement the Hague Convention in as comprehensive a manner as the United States because they do not have the legal structure to implement such drastic changes. Countries in these types of situations need help from member countries and time to implement new changes.

In the meantime, if adoption procedures are completely corrupt, a member country always has the option of suspending adoptions from the non-member country. However, most countries only resort to suspension in serious cases of corruption and abuse. ${ }^{106}$

102. Oona Hathaway, Do Human Rights Treaties Make a Difference, 111 Yale L.J. 1935, 2013 (2002).

103. Harty, supra note 12.

104. Examples among the top sending countries: Ukraine is dealing with political and economic transformations as well as high crime. U.S. Department of State, Consular Information Sheet: Ukraine, http://travel.state.gov/travel/cis_pa_tw/cis/cis_1053.html (last visited Feb. 27, 2008). Liberia is unstable and in the process of rebuilding its infrastructure. Crime and corruption are serious problems. U.S. Department of State, Consular Information Sheet: Liberia, http://travel.state.gov/travel/cis_pa _tw/cis/cis_950.html (last visited Feb. 27, 2008). Russia is also dealing with political and economic transformations. U.S. Department of State, Consular Information Sheet: Russian Federation, http:// travel.state.gov/travel/cis_pa_tw/cis/cis_1006.html (last visited Feb. 27, 2008).

105. See sources cited supra note 104.

106. For example, the United States suspended adoptions with Cambodia due to corruption and abuse. See Cambodia, supra note 97. 


\section{B. Reasons for Allowing Adoptions to Proceed from Member Countries that Have Not Implemented Convention Standards after the United States' Ratification of the Convention}

Guatemala should be given no fewer adoption rights than non-member countries. Banning adoptions from non-member countries after the United States' ratification of the Hague Convention would be heartless, and the opportunity for United States citizens to adopt would decrease dramatically or would shift to other countries. ${ }^{107}$ The United States will not ban adoptions from non-member countries, ${ }^{108}$ so it should not ban adoptions in Guatemala. Out of the top ten sending countries for the United States, in 2006, only four countries agreed to be bound by the Hague Convention. ${ }^{109}$ Unreasonableness in only allowing member countries to adopt is apparent by the small number of countries that choose to allow only Hague Convention adoptions. ${ }^{110}$ There are many more member countries that allow adoptions with non-member countries than those that do not." The United States will not turn its back on non-member country adoptions, so why should it turn its back on Guatemala?

A prohibition on adoptions in Guatemala would leave many children without families because national adoption is not an attractive or feasible option within the country. ${ }^{112}$ In 2006, Guatemala was the second top sending country in the United States and visas were issued to 4,135 children. ${ }^{113}$ There is a high demand by United States parents for adopted children from Guatemala. ${ }^{114}$ Even if adoptions

107. See Immigrant Visas, supra note 14.

108. See Prospective Adoptive Parents, supra note 31 , at 5.

109. See Immigrant Visas, supra note 14; Prospective Adoptive Parents, supra note 31, at 8-9. According to the U.S., the countries that have agreed to be bound by the Convention are China (1), Guatemala (2), Colombia (9), and India (10). The countries that have not agreed to be bound by the Convention include Russia (3), South Korea (4), Ethiopia (5), Kazakhstan (6), Ukraine (7), and Liberia (8).

110. See sources cited supra note 79.

111. For examples, see Hague Conference on Private International Law, Publications: United Kingdom, http://hcch.e-vision.nl/index_en.php?act=publications.details\&pid $=3698 \& \mathrm{dtid}=32$; Hague Conference on Private International Law, Publications: Canada, http://hcch.e-vision.nl/ index_en.php? act=publications.details $\&$ pid $=3671 \& \mathrm{dtid}=32$; Hague Conference on Private International Law, Publications: Germany, http://hcch.e-vision.nl/index_en.php?act=publications. details\&pid $=3679 \&$ dtid $=32 ;$ Hague Conference on Private International Law, Publications: France, http://hcch.e-vision.nl/index_en.php? act=publications.details $\&$ pid $=3678 \& d$ tid $=32$.

112. Ethica, Guatemala (Feb. 2003), http://www.ethicanet.org/item.php? recordid = guatemalappaper.

113. Immigrant Visas, supra note 14.

114. See id. 
were banned between the United States and Guatemala, many prospective parents would find new countries to adopt from, but that still does not change the problem of children needing homes or living in institutions.

The United States is working with Guatemala to implement Hague Convention guidelines, but it will take more time. Guatemala has requested help from the Permanent Bureau of the Hague Conference on Private International Law and several member countries to aid with implementation. ${ }^{15}$ Countries should not be bullied into implementation through the threat of banning adoptions. ${ }^{116}$ However, a country that has agreed to be bound by the Convention should not be given a free pass to disregard its obligations. If the United States wants to encourage Hague Convention requirements, it would be best to keep a continuing relationship with Guatemala and allow adoptions to proceed so long as the country is making strides toward compliance. Guatemala has made strides toward compliance by issuing a "Manual of Good Practices" relating to adoption law. ${ }^{117}$ The Guatemalan Congress has also passed legislation creating a Central Authority (National Council on Adoptions) and is providing for safeguards in its efforts to abide by Hague Convention standards. ${ }^{118}$ The United States needed approximately seven years to implement the Hague Convention from the time the implementing legislation was passed until ratification. ${ }^{119}$ Implementation is a slow process and cannot be expected immediately. Currently, Guatemala's only option is to comply minimally with the Hague Convention because of the short time frame given to prevent a ban on adoptions.

Hague Convention compliance in Guatemala will not occur if the United States decides to discontinue adoptions. If the United States were to halt adoptions, there would be no external pressure on Guatemala to comply with Convention requirements. For example, no substantial compliance has occurred in Guatemala since five other member countries objected to Guatemala's accession. ${ }^{120}$ Halting adoptions ignores the underlying problems Guatemala is facing. For example, Guatemala faces difficulties similar to those mentioned above for non-member countries. ${ }^{121}$ One

115. Congressional Coalition on Adoption Institute, Guatemala: Status of Intercountry Adoptions and the Hague Convention, http://www.ccainstitute.org/detail.php?id=151 [hereinafter Congressional Coalition].

116. Barry, supra note 13; Harty, supra note 12.

117. Congressional Coalition, supra note 115.

118. U.S. Department of State, Guatemalan Congress Passes Adoption Legislation, http://travel .state.gov/family/adoption/intercountry/intercountry_3903.html.

119. See Harty, supra note 12.

120. See Hague Details, supra note 71.

121. Compare sources cited supra note 104 (describing conditions in non-member countries) with U.S. Department of State, Consular Information Sheet: Guatemala, http://travel.state.gov/travel/ 
study has shown that with regards to human rights, ratification of treaties is linked with poorer human rights conditions and occurs at higher rates among countries with worse human rights. ${ }^{122}$ "[G]overnments and the individuals who make decisions within them become habituated to engaging in human rights violations and this behavior takes time and continued conscious effort to change." ${ }^{23}$ On the other hand, once a country begins to abide by treaty standards, those standards become concrete and are more difficult to displace. ${ }^{124}$ With help from the United States, Guatemala can displace old adoption methods and create Hague Conventioncompliant processes that will become concrete practices.

In addition, Guatemala would be able to offer different requirements that could meet a broader array of potential parents' needs. For example, Guatemala has minimal requirements for a person who would like to adopt, provided the prospective parent can pass adoption requirements within his or her own country. Nominal requirements for adoption allow a greater number of prospective parents to adopt and encourage non-traditional families. The requirements for adoption in Guatemala include less restrictive age requirements (no younger than the age of 18) and no marriage requirements. ${ }^{125}$ There are also no exclusions based upon medical conditions of the prospective parents and no exclusions based on age difference between the adopted children and the parents. ${ }^{126}$ This greatly contrasts with the requirements of other countries. China, for instance, which has passed new stringent guidelines for adoptive parents, severely restricts the number of couples who are able to adopt. ${ }^{127}$

While Guatemala is trying to implement Hague Convention requirements, the United States could enforce special requirements to prevent certain abuses as it strives toward implementation. For example, the United States has placed restrictions on Guatemala that prevent one form of child trafficking. Two DNA

cis_pa_tw/cis/cis_1129.html (stating the conditions in Guatemala).

122. Hathaway, supra note 102, at 2001, 2004.

123. Id. at 2003.

124. See id. at 2004.

125. Intercountry Adoption: Guatemala, supra note 19.

126. Id.

127. See U.S. Department of State, Requirements for Intercountry Adoption from Republic of China, http://travel.state.gov/family/adoption/intercountry/intercountry_3110.html (detailing restrictions on marital status, age, health, employment, income, education, family size, and moral character) (last visited Feb. 27, 2008). See also Beth Nonte Russell, The Mystery of the Chinese Baby Shortage, N.Y. TIMEs, Jan. 23, 2007, at A19, available at http://www.nytimes.com/2007/01/23/ opinion $/ 23 \mathrm{russell}$.html e $\mathrm{e}=5088 \& \mathrm{en}=92 \mathrm{c} 0 \mathrm{e} 7 \mathrm{c} 873 \mathrm{clc} 086 \& \mathrm{ex}=1327208400 \&$ partner $=$ rssnyt $\& \mathrm{emc}=$ rss $\&$ pagewanted = print (discussing the reasons for the new restrictions). 
tests for a birth mother giving consent for the adoption are required so that a female posing as the birth mother cannot fraudulently give consent for the adoption. ${ }^{128} \mathrm{~A}$ ban on adoptions until Guatemala complies is not the answer. Guatemala needs the United States' help and more time for further implementation.

\section{Conclusion}

The Hague Convention was designed to promote adoptions in "the best interests of the child" and to prevent abuses such as child trafficking and buying. For member countries, the United States' ratification of the Hague Convention enables standard rules to be applied for adoption between member countries; the Hague Convention creates more conformity among adoption systems in order to prevent harm to adopted children. For non-member countries, the United States' ratification of the Hague Convention will not make a difference, and adoptions can be conducted as usual with little regard for Convention standards. However, for member countries not abiding by Hague Convention standards, the United States' ratification may cause a ban on adoptions between the countries. Member countries unable to implement the Hague Convention are being punished for agreeing to be formally bound by the Hague Convention because they cannot implement the Convention requirements even though their inability to implement the Convention stem from political, governmental, and judicial problems. Member countries want to encourage Hague Convention participation and compliance. However, the threat of banning adoptions for noncompliance with the Hague Convention encourages nonmembers to avoid making the initial commitment to the Hague Convention because they could face the same difficulties as Guatemala-agreeing to the Hague Convention but unable to implement it. If member countries want to encourage countries to accede to the Hague Convention, banning adoptions from countries that have agreed to the Hague Convention but have yet to implement those standards is not the way.

The United States should not ban adoptions with Guatemala because it has much to offer prospective parents, and in return the United States can help Guatemala comply with the Hague Convention. Guatemala has made adoption a priority, and it needs more time to implement the Hague Convention. Current work and pressure from the United States to achieve this goal shows commitment, but with the complex nature of implementation, as indicated by the United States' efforts,

128. Congressional Coalition on Adoption Institute, http://www.ccainstitute.org/detail.php $?$ id $=155$. 
Guatemala will need more time to comply with Hague Convention standards. Placing a ban on adoptions with Guatemala is an unnecessary and drastic move that harms "the best interests of the child." With more time and help from the United States, Guatemala can become a compliant member and make positive transformations within its adoption system to be an example for non-member countries. 


\section{THE JOURNAL OF}

\section{Legal Studies}

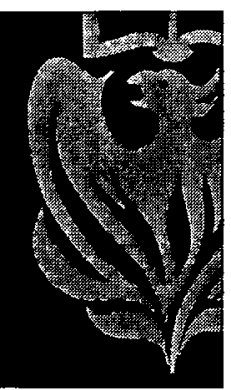

Cponsored by the University of Chicago Law School, The fournal of Legal Studies features theoretical and empirical research on law and legal institutions. Economists, political scientists, sociologists, historians, and legal scholars contribute to $/ L S$, emphasizing a social science approach.

Semiannual ISSN: 0047-2530

Print and Electronic, \$31 Electronic-only, $\$ 26$ Print-only, \$26

Student (Electronic-only), $\$ 16$

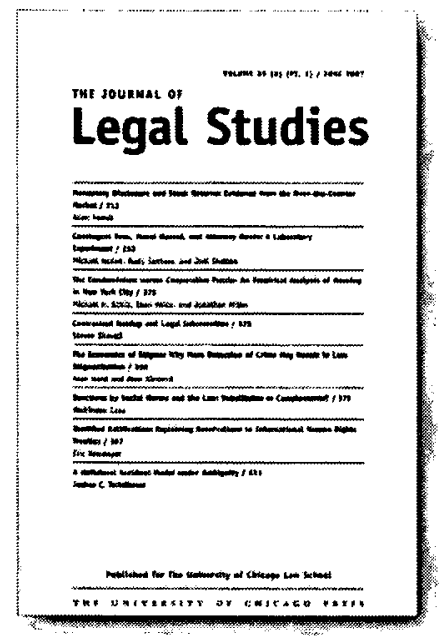

THE UNIVERSITY

OF CHICAGO PRESS

JOURVALS DIVISION

Editors

Eric A. Posner, Thomas J. Miles, University of Chicago Law School

To Subscribe Phone: 1.877 .705 .1878

1.773 .753 .3347

Fax: 1.877 .705 .1879

1.773 .753 .0811

www.journals.uchicago.edu/JLS 